\title{
UV RADIATION AND TEMPERATURE AFFECT VIABILITY OF SERRATIA SPP., POTENTIAL BIOCONTROL AGENTS OF INSECTS
}

\author{
J.F. PEARSON, L.M. HUNT \\ and K.J. MITCHELL \\ Biocontrol and Biodiversity Group, Grasslands, \\ AgResearch, P.O. Box 60, Lincoln
}

\begin{abstract}
Several species within the genusSerratia (Enterobacteriaceae) have potential for use, or are currently used, in the control of insect pests. However, as with most microbes, exposure to certain UV wavelengths can drastically reduce cell viability. In this study we investigated the effect of exposure to short $(254 \mathrm{~nm}) \mathrm{UV}$ radiation and natural sunlight on strains of Serratia. Exposure to $254 \mathrm{~nm}$ for 5-30 minutes killed most Serratia spp.; however, there were considerable strain differences with the $\mathrm{LT}_{50}$ ranging from 2.9 to 13.7 minutes. Survival time increased to more than $2+$ hours under sunlight exposure but was dependent the bacterial broth temperature.
\end{abstract}

Keywords: artificial UV, sunlight, Serratia spp., strains, $\mathrm{LT}_{50}$

\section{INTRODUCTION}

In the last two decades the "green revolution" has brought with it a trend towards the development of organic "environmentally friendly" products. The non-polluting characteristics of biological control agents for pest control have many advantages over agrochemicals. Bacteria in the genusSerratia (Enterobactericaceae) are currently under development, or have been developed, as control agents for several insect pests. $S$. entomophila, for example, has been developed as a commercial pesticide (Invade) for the control of grass grub, Costelytra zealandica (Jackson et al. 1992). S. marcescens and S. proteamaculans have shown potential as control agents of Diptera (O'Callaghan et al. 1996). Despite their promise, the use of Serratia in many situations such as its application in spray form, could be limited by the effects of ultra-violet radiation (UV). Ozone is an important trace gas that provides the earth's protective UV shield; however, a long term decrease of $0.5 \%$ per year of the total ozone values is predicted for New Zealand (Matthews and Keep 1993). A future likely increase in UV intensity, makes it necessary to determine the susceptibility of Serratiaspp. to exposure from natural and artificial UV radiation early in the biopesticide development.

\section{Strains and culturing}

\section{METHOD}

Eleven strains of bacteria from the genusSerratia, all held in the AgResearch Insect Pathogen Culture Collection (Lincoln), were used in the UV exposure experiments (Table 1).

Each strain was aseptically streaked onto Luria Bertani (LB) agar (Sambrooket al. 1989) and incubated overnight at $30^{\circ} \mathrm{C}$. To produce inoculum for experiments, a single isolate from each strain was inoculated into a sterile universal bottle containing $10 \mathrm{ml} \mathrm{LB}$ broth and placed in a shaking water bath overnight $\left(30^{\circ} \mathrm{C}, 80 \mathrm{rpm}\right)$. 
TABLE 1: Strains of Serratia spp. used in this study.

\begin{tabular}{cll}
$\begin{array}{l}\text { Species, } \\
\text { Strain no }\end{array}$ & $\begin{array}{l}\text { Biotype, } \\
\text { Pigmentation }\end{array}$ & Origin and host \\
\hline S. entomophila & & \\
190 & $1, \mathrm{np}$ & Subculture A1 strain, Costelytra zealandica \\
304 & $1, \mathrm{np}$ & Derived from A1MO2 strain by EMS \\
483 & $2, \mathrm{np}$ & CI1 strain, Chatham Islands, soil isolate \\
625 & $1, \mathrm{np}$ & Non pathogenic strain from original 154 mixed strain \\
626 & $1, \mathrm{np}$ & Original pathogenic 154 strain, Costelytra zealandica
\end{tabular}

S. proteamaculans

$142 \quad-, \mathrm{np}$

Tihoi, Taupo, NZ, Costelytra zealandica

S. marcescens

363 A2a, p Lincoln, NZ, Paropsis charybdis

392 A6a?, p Lincoln University farm, NZ, soil isolate

448 A1a, p Pasteur Institute, Grimont, Periplanta americana

$450 \quad$ A6a, p Pasteur Institute, Grimont, Hylamorpha elegans

$505 \quad$ A4a, np Chile, Hylamorpha elegans

${ }^{1} \mathrm{np}=$ non pigmented, $\mathrm{p}=$ pigmented

\section{Experiment 1: exposure to $254 \mathrm{~nm}$ UV radiation}

The source of the UV radiation was a $254 \mathrm{~nm}$ tube housed in a Class II Biological Safety Cabinet. On the working bench surface $(600 \times 400 \mathrm{~mm})$, a grid of a petri dish lids was arranged $550 \mathrm{~mm}$ beneath the UV light source. Variation in UV intensity was detected using an International Light, model IL1400A, detection head SEL 2403491 , with NS254 and W6557 sensing head. Each bacterial strain (Table 1) was tested with at least three replicates at varied positions within the cabinet to take account of variation in light intensity. The limited working space allowed a maximum of five strains to be tested per sub-experiment $1 \mathrm{a}, \mathrm{b}$ and $\mathrm{c}$ with the inclusion of two strains 626 and 142 in each sub-experiment in order to standardise the exposure to a possible change in ambient temperature.

A $2 \mathrm{ml}$ aliquot from each culture was pipetted into the centre of five inverted petri dish lids for UV exposure. One broth culture per strain was removed after 0 (control treatment), 5, 10, 20 and 30 min of radiation at ambient temperature; Pearson et al. (1993) reported no loss in Serratia sp. viability following <12 hours at ambient temperature packaged in opaque plastic containers. Bacterial survival was determined from colony counts of serial dilutions from each sample plated onto LB agar and incubated at $30^{\circ} \mathrm{C}$ overnight. The bacterial concentration was expressed as $\%$ survival of the control count. The $\mathrm{LT}_{50}$ (min to $50 \%$ survival) was calculated for each strain. Fresh cultures were prepared for each replicate test through the experiment. The range of the original concentrations was $0.5-4 \times 10^{9}$ colony forming units $(\mathrm{cfu}) / \mathrm{ml}$.

\section{Experiment 2: exposure to natural UV}

In this experiment two replicates of $S$. entomophila strain 626 were exposed to natural UV under two temperature regimes. Four $\mathrm{ml}$ aliquots of bacteria were pipetted into each of 24 petri dishes which were placed in trays in full sunshine for up to five hours on March 201997 commencing at 9.45 am. Differential temperatures, ambient and chilled, were achieved by placing 12 petri dishes on ice. Temperatures for each treatment were recorded by probe at 30 minute intervals for both treatments. Addition of distilled water was necessary in the ambient trays to compensate for evaporation and in the chilled treatment, allowance was made for condensation on the dishes. Duplicate samples were removed after 0 (control treatment), 2, 2+, 3, 3+, 4 and 5 hours and bacterial numbers determined by plating onto Serratia selective agar, caprylate thallous agar (Starr et al. 1976), to minimise contamination. The plates were incubated at $30^{\circ} \mathrm{C}$ for five days, prior to recording colony counts. The $\mathrm{LT}_{50}$ was calculated for each temperature. An estimate 
of the mean treatment temperature was based on the mean temperatures prior to reaching the $\mathrm{LT}_{50}$.

\section{Statistical analysis}

$\mathrm{LT}_{50} \mathrm{~S}$ were calculated by fitting Logit curves to predicted means. The statistical analysis used was REML (Residual Maximum Likelihood) analysis as the experimental design was an incomplete block design. This method of analysis gives maximum and minimum standard errors of the differences between strains and estimates the strain means (Genstat 5 Committee 1993).

\section{RESULTS}

There were significant differences between several of the predicted $\%$ survival $(\mathrm{P}<0.05)$ for strains exposed to $254 \mathrm{~nm}$ (Table 2$)$.

TABLE 2: Predicted mean \% survival and $\mathrm{LT}_{50}$ at four time periods of $254 \mathrm{~nm}$ UV exposure.

\begin{tabular}{|c|c|c|c|c|c|c|}
\hline \multirow[b]{2}{*}{$\begin{array}{l}\text { Time (min) } \\
\text { Strain }\end{array}$} & \multirow[b]{2}{*}{$\begin{array}{c}\text { No. } \\
\text { of expts. }\end{array}$} & \multirow[b]{2}{*}{5} & \multicolumn{3}{|c|}{ Means (REML estimates ${ }^{1}$ ) } & \multirow[b]{2}{*}{$\begin{array}{c}\mathrm{LT}_{50} \\
\text { (estimated) }\end{array}$} \\
\hline & & & 10 & 20 & 30 & \\
\hline 190 & 1 & 54.5 & 26.5 & 5.6 & 2.2 & 5.6 \\
\hline 304 & 1 & 29.5 & 13.5 & 1.7 & 0.5 & 2.9 \\
\hline 483 & 1 & 37.3 & 7.0 & 2.4 & 0.9 & 4.0 \\
\hline 625 & 1 & 70.2 & 33.5 & 8.1 & 2.6 & 7.6 \\
\hline 626 & 3 & 50.2 & 26.7 & 5.6 & 1.6 & 5.0 \\
\hline 142 & 3 & 65.3 & 26.4 & 6.6 & 1.9 & 6.7 \\
\hline 363 & 1 & 56.5 & 28.0 & 5.5 & 1.1 & 5.9 \\
\hline 392 & 1 & 76.8 & 50.0 & 9.4 & 1.7 & 9.8 \\
\hline 448 & 1 & 88.1 & 69.2 & 23.1 & 7.0 & 13.7 \\
\hline 450 & 1 & 85.1 & 33.3 & 8.4 & 4.3 & 8.5 \\
\hline 505 & 1 & 79.8 & 37.5 & 12.6 & 2.8 & 8.6 \\
\hline \multicolumn{7}{|c|}{ LSD $(5 \%)$ for comparison of: } \\
\hline (min.,ma & Ix.) & $22.4,27.7$ & $21.5,24.9$ & $5.9,6.7$ & $2.4,2.7$ & \\
\hline \multicolumn{7}{|c|}{ means from 1 expt. with } \\
\hline mean frol & m 3 expt. & $19.3,22.7$ & $18.8,19.5$ & $4.9,5.8$ & $2.0,2.3$ & \\
\hline means from & 3 expt. & 12.9 & 12.4 & 3.4 & 1.4 & \\
\hline
\end{tabular}

${ }^{1}$ REML, residual maximum likelihood; see methods

The average strain $\mathrm{LT}_{50}$ values ranged from 2.9-13.7 minutes. The most resistant strains were all from the $S$. marcescens species. The pigmented $S$. marcescens 448 strain had the highest resistance to UV $254 \mathrm{~nm}$ with $88.1 \%$ survival after $5 \mathrm{~min}$ exposure. Two of the S. entomophila strains had the least resistance to UV, with 29.5 and $37.3 \%$ survival after 5 min for the 304 and 483 strains.

TABLE 3: Mean \% survival (and temperature ${ }^{\circ} \mathrm{C}$ ) for strain 626 exposed to sunlight at two temperature regimes.

\begin{tabular}{ccccccc}
\hline & \multicolumn{7}{c}{ Time $-\min$} \\
Temperature & 120 & 150 & 180 & 210 & 240 & 300 \\
\hline Ambient $\left({ }^{\circ} \mathrm{C}\right)$ & 109.0 & 147.6 & 164.4 & 24.6 & 11.0 & 0.8 \\
& $(17.2)$ & $(26.0)$ & $(18.8)$ & $(18.3)$ & $(17.4)$ & $(25.0)$ \\
Chilled $\left({ }^{\circ} \mathrm{C}\right)$ & 67.4 & 71.3 & 35.5 & 42.7 & 10.5 & 4.1 \\
& $(3.4)$ & $(7.5)$ & $(5.6)$ & $(5.1)$ & $(6.5)$ & $(8.0)$ \\
Significance $^{1}$ & $* *$ & $*$ & $*$ & $* *$ & NS & NS \\
\hline
\end{tabular}

${ }^{1} \mathrm{NS} \mathrm{P}>0.05, * \mathrm{P}<0.05$ and $* * \mathrm{P}<0.01$ 
Analysis of experiment 2 showed significant differences between the two temperature regimes under natural sunlight (Table 3 ), with reduced survival at lower and bacterial multiplication at ambient temperatures. The $\mathrm{LT}_{50}$ was 168 minutes at $5.6^{\circ} \mathrm{C}$ and 204 minutes at $16.3^{\circ} \mathrm{C}$.

\section{DISCUSSION}

The results of these two experiments indicate that time to death of bacteria by UV radiation is dependent on UV wavelength and temperature. Rapid death was expected and strain variation found from bacterial exposure to short-wave $254 \mathrm{~nm}$ - the wavelength used in germicidal applications. Two strains, 304, a chemically mutated strain, and 483, which originated from the Chathams, were the most susceptible of the S. entomophila strains. Bacterial pigmentation may assist survival as three out of the four most resistant $S$. marcescens strains were pigmented.

The short wavelengths $(290-320 \mathrm{~nm})$ represent $<1 \%$ of the total solar radiation received on the earths surface (McKenzie 1993). Therefore it was not surprising to find that bacteria in liquid media survived for a longer period when placed in sunlight $\left(\mathrm{LT}_{50}\right.$ in sunlight 168-204 min compared with an $\mathrm{LT}_{50}<14$ minutes at $254 \mathrm{~nm}$ ). For the first two hours of experiment 2 , the mean ambient temperature was $<15^{\circ} \mathrm{C}$; increasing to $26^{\circ} \mathrm{C}$ before the third hour of exposure. This rise in temperature corresponded to the cells multiplication to $164.4 \%$ prior to declining in number. The bacterial growth increased the survival time of the ambient culture compared to the ice cooled culture in which no cell multiplication occurred.

Resistance to UV radiation is a component of 'microbial fitness' $(\mathrm{O}$ 'Callaghan and Jackson 1996) and further work is needed to assess the relative survival of the bacterial strains under sunlight as compared with the strain differences under UV $254 \mathrm{~nm}$. However, such comparisons would need to take into account the considerable natural variations in the UV intensity of sunlight.

\section{ACKNOWLEDGEMENTS}

We would like to thank Sandra Young and Tracey Nelson for technical assistance. DrDavid Baird assisted in the experimental design. Tony Dixon, Advanced Clean Room Systems provided reference material and the UV $254 \mathrm{~nm}$ intensity meter. This research was partly funded under the AgResearch Summer Scholarship Programme.

\section{REFERENCES}

Genstat 5 Committee, 1993. Genstat 5 Release 3 Reference Manual. Oxford Science Publications, UK.

Jackson, T.A., Pearson, J.F., O’Callaghan, M., Mahanty, H.K. and Willocks, M.J., 1992. Pathogen to product - development ofSerratia entomophila (Enterobacteriacae) as a commercial biological control agent for the New Zealand grass grub (Costelytra zealandica). Pp 191-198. In: Use of Pathogens in Scarab Pest Management. T.A. Jackson and T.R. Glare (Eds). Intercept, Andover, UK.

Matthews, W.A. and Keep, D.J., 1993. Ozone trends and variability, globally and over New Zealand. Pp 2-3. In: Proceedings of the National Science Strategy Committee for Climate Change Workshop. Miscellaneous Series 25, Royal Society of New Zealand.

McKenzie. R.L., 1993. UVB and its global variability. Pp 3-4. In: Proceedings of the National Science Strategy Committee for Climate Change Workshop. Miscellaneous Series 25, Royal Society of New Zealand.

O'Callaghan, M., Garnham, M.T., Nelson, T.L., Baird, D. and Jackson, T.A., 1996. The pathogenicity of Serratia strains to Lucilia sericata (Diptera: Calliphoridae). J. Invert. Path. 68: 22-27.

O’Callaghan, M. and Jackson, T.A., 1996. Introduction of mass produced microorganisms into the soil environment. Pp 89-94. In: Proceedings of the 3rd International Workshop on Microbial Control of Soil Dwelling Pests. T.A. Jackson and T.R. Glare (Eds). 
Pearson, J.F., Young, S.D. and Jackson, T.A., 1993. Longevity of high densitySerratia entomophila cultures under refrigerated and ambient conditions. Proc. 46th N.Z. Plant Prot. Conf.: 237-238 (Research note).

Sambrook, J., Fritsch, E.F. and Maniatis, T., 1989. Molecular Cloning: A Laboratory Manual 2nd edn., Cold Spring Harbour Laboratory Press.

Starr, M.P., Grimont, F. Grimont P.A.D. and Starr, P.B., 1976. Caprylate thallous agar medium for selectively isolatingSerratia and its utility in the clinical laboratory.J. Clinical Micro. 4: 270-276. 